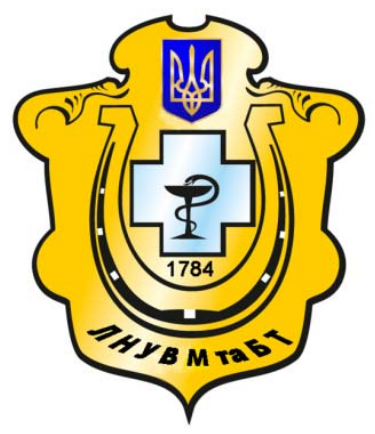

Науковий вісник Львівського національного університету ветеринарної медицини та біотехнологій імені С.3. Гжицького

Scientific Messenger of Lviv National University of Veterinary Medicine and Biotechnologies named after S.Z. Gzhytskyj

doi:10.15421/nvlvet7307

ISSN 2518-7554 print

ISSN 2518-1327 online

$\underline{\text { http://nvlvet.com.ua/ }}$

УДК 639.3.043:597.552.512

\title{
ВПлив згодовування плідникам райдужної форелі ганаміновіту на виживання заплідненої ікри та передличинок
}

\author{
Н.С. Гриневич \\ gnatbc@mail.ru \\ Білочерківський національний аграрний університет, \\ пл. Соборна, 8/1,м. Біла Церква, 09117, Україна
}

\begin{abstract}
Вивчено вплив згодовування плідникам райдужної форелі (Oncorhynchys mykiss) разом із екструдованим комбікормом вітамінної добавки - ганаміновіт на відсоток виживання заплідненої ікри та передличинок до маси 0,3 г. Встановлено, шо в умовах замкненого водопостачання у переднерестовий та післянерестовий періоди маточне поголів'я райдужної форелі потребує додаткових вітамінних добавок, окрім тих, щзо включені у склад сучасних еструдованих комбікормів. Внесення добавки впродовж двох місяиів, перед інкубачією, сприяє швидиому відновленню організму у післянерестовий період $і$ сприяє підвищенню імунітету та вищому відсотку виживання ікри та передличинок до маси 0,3 г. Загибель ікри на стадії вічка, одержаної від плідників, щчо виступали контролем, становила 61,7\% а зростання маси личинок при переході на активне живлення у 2015 роцуі-0,041 г. У 2016 роциі изі показники були вищими і становили відповідно 79,4\% та 0,052 г.

Продуктивний ефект личинки райдужної форелі за згодовування плідникам ганаміновіту сприяє зростанню маси личинок при переході на активне живлення. Доцільно продовжити дослідження темпу росту різних вікових груп райдужної форелі за дії вітамінної добавки - ганаміновіт.

Ключові слова: райдужна форель, вітамінна добавка, плідники, ікра на стадї вічка, передличинка, екструдовані комбі-
\end{abstract} корми.

\section{Влияние скармливания производителям радужной форели ганаминовита на выживаемость оплодотворенной икры и предличинок}

\author{
Н.Е. Гриневич \\ gnatbc@mail.ru \\ Белоиерковский национальный аграрный университет, \\ пл. Соборная, 8/1,м. Белая Церковь, 09117, Украина
}

\begin{abstract}
Изучено влияние скармливания производителям радужной форели (Oncorhynchys mykiss), вместе с экструдированным комбикормом витаминной добавки - ганаминовит на проиент выживания оплодотворенной икры и передличинок к массе 0,3 г. Установлено, что в условиях замкнутого водоснабжения в преднерестовый и посленерестовый периоды маточное поголовье радужной форели требует дополнительных витаминных добавок, кроме тех, которые включены в состав современных еструдованих комбикормов. Внесение добавки в течение двух месячев, перед инкубацией, способствует быстрому восстановлению организма в посленерестовый период и способствует повымению иммунитета и высоком проценте выжсиваемости икры и передличинок к массе 0,3 г. Гибель икры на стадии глазка, полученной от производителей, которые выступали контролем, составила 61,7\%, а рост массы личинок при переходе на активное питание в 2015 году - 0,041 г. B 2016 году эти показатели были выше и составляли соответственно 79,4\% и 0,052 г.
\end{abstract}

Ключевые слова: радужная форель, витаминная добавка, производители, икра на стадии глазка, предличинки, экструдированные комбикорма.

Citation:

Grynevych, N. (2017). The effect of feeding breeding stock of rainbow trout with Ganaminovit on the survival of fertilized eggs and pre-larvae. Scientific Messenger LNUVMBT named after S.Z. Gzhytskyj, 19(73), 33-36. 


\title{
The effect of feeding breeding stock of rainbow trout with Ganaminovit on the survival of fertilized eggs and pre-larvae
}

\author{
N. Grynevych \\ gnatbc@mail.ru

\begin{abstract}
Belotserkovskii national agrarian university, Soborna sq., 8/1, Bila Tserkva, 09111, Ukraine
\end{abstract}

\begin{abstract}
The aim of research was a study the effect of influence of feeding by feed supplement of Ganaminovit the breeding stock of rainbow trout on the state of fertilized eggs and pre-larvae. The task of research was to study influence of Ganaminovit on the survival of fertilized eggs and on the productive effect of larvae in the conditions of the closed water-supply. The breeding stock of rainbow trout were fed by the extruded mixed fodders with Ganaminovit in 2015 during two months to and after spawning and in 2016 before spawning.

The influence of feeding rainbow trout breeding stock, along with extruded feed vitamin supplements - Ganaminovit on the survival rate of fertilized eggs and pre-larvae for the mass of $0.3 \mathrm{~g}$. It is established that in conditions of closed water system in the prespawning and after-spawning periods of the breeding stock of rainbow trout requires additional vitamin supplements, other than those included in the modern extruded food. The introduction supplements for two months, before incubation, promotes more rapid recovery of the body in after-spawning period and enhances immunity and high survival rates of eggs and of pre-larvae for the mass of $0.3 \mathrm{~g}$. Mortality of eggs in the control group of breeding stock at the stage of the eye was $61.7 \%$, and the increase of weight of the larvae during transition to active feeding in 2015 - $0.041 \mathrm{~g}$. In 2016, these figures were higher and amounted to respectively $79.4 \%$ of and $0.052 \mathrm{~g}$.
\end{abstract}

Key words: rainbow trout, vitamin supplement, breeding stock, stage of the eye, pre-larvae, extruded feed.

\section{Ветуп}

Євросоюз визнає екологічно чистою тільки ту рибну продукцію, яка вирощена в установках замкненого водопостачання (УЗВ) (Chrustslev et al., 2010; Hrustalev et al., 2014). Вирощування райдужної форелі в УЗВ належать до вищої форми індустріального рибництва i, на відміну від форелевих господарств на відкритій воді, має свою особливість - обмежену територію. Саме тому за інтенсивної системи контрольованого вирощування надзвичайно великі вимоги ставляться до рибопосадкового матеріалу, який мусить мати стійкий імунітет до заразних хвороб, оскільки 3 нього, на 80,0\%, формується майбутнє маточне поголів'я (Grudniewska et al., 2011; Hrustalev et al., 2014). Згідно 3 технологічними нормами плідники райдужної форелі, а це в основному осінньонерестуючі особини, цілий рік отримують спеціальні комбікорми. Власний досвід показує, що за отримання високоякісної ікри добре себе зарекомендував збалансований корм для риби ALLER REP EX, який має такі характеристики: сирий протеїн - 53,0\%, сирий жир $14,0 \%$, вуглеводи $-15,0 \%$, зола $-9,0 \%$, клітковина $1,1 \%$, загальна енергія - 4974 Ккал або 20,8, МДж і перетравна енергія 3928 Ккал або 16,4 МДж (Sharre et al., 2005). Важливим $є$ те, що у склад корму входити астаксантин i кантаксантин, які, крім підвищення якості ікри, сприяють і розвитку вторинних статевих ознак у риб-плідників (Barylo and Hrynevych, 2015; Hrynevych, 2016). Разом 3 цим, комбікорм ALLER REP EX $є$ недостатньо енергетичним для плідників i, враховуючи екологічні умови проведення інкубації та інші впливи, від яких можливі негативні наслідки для повносистемного господарства, для швидкого відновлення маси тіла у післянерестовий період, рекомендується застосування більш калорійних комбікормів 3 відповідним вітамінним складом (Davydov et al., 2009; Vodianitskyi et al., 2016). Крім корму, на життєдіяль- ність риби в УЗВ впливають ксенобіотики і чинники навколишнього середовища, які приводить до надмірного використання вітамінів (Shemchuk and Pirus, 2002; Ponomareva et al., 2005; Pukalo et al., 2012; Smolynets' et al., 2016), що свідчить про актуальність роботи. Тому, за результатами пошуку препаратів зареєстрованих в Україні, які були б ефективні за вирощування риби в УЗВ, нами була вибрана кормова добавка ганаміновіт.

Мета $і$ завдання досліджень. Метою роботи було вивчення впливу згодовування плідникам райдужної форелі кормової добавки ганаміновіт на стан ікри і передличинки. Завдання - вивчити вплив на виживання ікри ганаміновіту, який у 2015 році протягом двох місяців до та після нересту і у 2016 році до нересту згодовували плідникам разом 3 екструдованими комбікормами, а також дослідити вплив ганаміновіту на продуктивний ефект личинки в умовах замкненого водопостачання

\section{Матеріал і методи досліджень}

Дослідження проводилися у Східноукраїнському центрі з розведення цінних видів риб протягом 2015 та 2016 років на двох групах плідників райдужної форелі (Oncorhynchys mykiss) у кількості 200 шт. у кожній, одна з яких слугувала контролем (К), інша дослідною (Д), яка протягом двох місяців до та після нересту разом з екструдованими комбікормами отримувала вітамінну добавку - ганаміновіт в дозі 7,0 г на 100 кг корму. Згодовування вітамінної добавки проходило протягом двох інкубаційних сезонів. Біологічним матеріалом слугували запліднена ікра та ікра на стадії вічка та передличинка. Дослідження з виживання заплідненої ікри та передличинок проводили протягом п'яти місяців, від першого дня інкубації ікри до виходу личинки вагою до 1,0 г, із листопада по березень. Запліднена ікра була отримана шляхом штучно- 
го відтворення, перебувала в горизонтальних апаратах Шустера і підлягала дії води, яка надходила в інкубатор зі свердловини через градильню.

Отримані дані оброблені статистично за допомогою програми Statistica 5.5, Epaprobit analysis program used for calculating LC/EC values (Version 1.5).

\section{Результати та їх обговорення}

Аналіз даних (табл. 1) з використання вітамінної добавки - ганаміновіт для плідників райдужної форелі в умовах замкненого водопостачання показав, що кількість мертвої ікри та загиблих личинок від першого дня інкубації ікри до виходу личинки вагою 3 г, порівняно із контрольною групою, зменшується i залежить від часу використання плідниками добавки. Так, у 2015 році від плідників, яким згодовували ганаміновіт протягом 2 місяців, виживання ікри, порівняно із контролем, було вищим на $24,7 \%$, тим часом, як у 2016 році даний показник зріс і становив 51,1\%. Таке високе виживання ікри і вихід личинок форелі у 2016 році ймовірно зв'язано із повторним використанням плідникам, а це $85,0 \%$ від плідників попереднього року, кормової добавки. Отже, згодовування протягом двох місяців плідникам Oncorhynchys mykiss ганаміновіту підвищує на 24,7\% вихід личинки від моменту запліднення ікри, порівняно із ікрою, одержаною від самців, що не одержували вітамінного комплексу. Повторне використання плідників, яким у 2015 році протягом двох місяців до та після нересту і у 2016 році до нересту разом з екструдованими комбікормами давали вітамінну добавку, підвищує збереження життєздатності ікри від першого дня iі інкубації і до виходу личинки вагою 3 г на 51,1\%.

Іншим показником, який свідчить про позитивний вплив ганаміновіту на здатність до виживання молоді райдужної форелі, є іiї приріст у фазі переходу на екзогенне живлення. Цей момент переходу із ендогенного на екзгенне живлення в аквакультурі, а особливо у форелівництві, вважаються ключовим. Перехід слід здійснити тоді, коли $80 \%$ личинки уже піднялося на плав, і у неї ще залишається $1 / 3$ частини жовткового мішечка. Така молодь швидше адаптується до гранульованих комбікормів, систематичного темпу росту риби та стійкості до бактеріальних захворювань. 3 огляду на те, що маса личинки незначна, контрольні зважування проводяться у кількості 100 штук. Інтенсивність росту, вага та морфологічні дані личинок у 2015-2016 рр. не відрізнялися суттєво як у контрольних, так і в дослідних групах (табл. 2).

Результати впливу згодовування плідникам райдужної форелі ганаміновіту на загибель заплідненої ікри на стадії вічка і передличинки в умовах замкненого водопостачання, $(\mathrm{M} \pm \mathrm{m}, \mathbf{n}=\mathbf{5 0 0 0})$

\begin{tabular}{|c|c|c|c|c|c|}
\hline \multirow{4}{*}{$\begin{array}{l}\text { Місяці дослі- } \\
\text { джень }\end{array}$} & \multirow{4}{*}{ Групи } & \multicolumn{4}{|c|}{ Роки дослідження } \\
\hline & & \multicolumn{2}{|c|}{2015} & \multicolumn{2}{|c|}{2016} \\
\hline & & \multicolumn{2}{|c|}{ Кількість загиблих ікринок } & \multicolumn{2}{|c|}{ Кількість загиблих ікринок } \\
\hline & & $\mathrm{n}$ & $\%$ & $\mathrm{n}$ & $\%$ \\
\hline \multirow{2}{*}{ Листопад } & K & 275 & 5,5 & 205 & 4,1 \\
\hline & Д & 284 & 5,7 & 217 & 4,3 \\
\hline \multirow{2}{*}{ Грудень } & K & 1138 & 22,7 & 1206 & 24,1 \\
\hline & Д & 893 & 17,8 & 656 & 13,1 \\
\hline \multirow{2}{*}{ Січень } & K & 694 & 13,9 & 1004 & 20,0 \\
\hline & Д & 386 & 7,4 & 361 & 7,2 \\
\hline \multirow{2}{*}{ Лютий } & K & 504 & 10,1 & 266 & 5,3 \\
\hline & Д & 209 & 4,2 & 114 & 2,3 \\
\hline \multirow{2}{*}{ Березень } & K & 473 & 9,5 & 291 & 5,8 \\
\hline & Д & 94 & 1,9 & 72 & 1,4 \\
\hline \multirow{2}{*}{ Всього } & K & 3084 & 61,7 & 2972 & 79,4 \\
\hline & Д & 1866 & 37,0 & 1420 & 28,3 \\
\hline
\end{tabular}

Таблиия 2

Продуктивний ефект личинки райдужної форелі за згодовування плідникам ганаміновіт, $(\mathbf{M} \pm \mathbf{m}, \mathbf{n}=100)$

\begin{tabular}{|c|c|c|c|c|c|}
\hline Дата & Ікра & Маса (100 шт) мг & $\begin{array}{c}\text { Дата } \\
2016 \mathrm{p}\end{array}$ & Ікра & \multirow{2}{*}{ Маса (100 шт) мг } \\
\hline \multirow{2}{*}{30.01} & К & $0,016 \pm 0,0003$ & 28.01 & К & $0,014 \pm 0,0014$ \\
& Д & $0,018 \pm 0,0003$ & 04.02 & К & $0,018 \pm 0,0003$ \\
\hline \multirow{2}{*}{03.02.} & К & $0,018 \pm 0,0003$ & Д & $0,023 \pm 0,00006$ \\
\hline \multirow{2}{*}{15.02} & Д & $0,021 \pm 0,0006$ & \multirow{2}{*}{15.02} & К & $0,024 \pm 0,0030$ \\
& Д & $0,023 \pm 0,0006$ & 26035 & $0,030 \pm 0,0055$ \\
\hline \multirow{2}{*}{25.02} & К & $0,027 \pm 0,0005$ & \multirow{2}{*}{26.02} & К & $0,042 \pm 0,0015$ \\
& Д & $0,046 \pm 0,0001$ & Д & $0,052 \pm 0,0017$ \\
\hline
\end{tabular}

Аналізуючи лінійний розвиток личинки райдужної форелі у розрізі років можна відмітити як стабільний, проте $\epsilon$ різниця між масою у контрольних і дослідних групах. Так, у 2015 році ця різниця на початку лютого становила 0,003 мг, а у 2016 р., коли плідники повторно отримали вітамінну добавку - 0,006 мг. У кінці лютого ця різниця у досліджуваних групах була сут- 
тєвою і у 2016 році маса переважає на 0,01 мг, а у 2015 році ця різниця становить лише 0,005 мг.

Отже, продуктивний ефект личинки райдужної форелі за згодовування плідникам ганаміновіту сприяє зростанню маси личинок при переході на активне живлення.

\section{Висновки}

1. Згодовування протягом двох місяців плідникам Oncorhynchys mykiss ганаміновіту підвищує на 24,7\% вихід личинки від моменту запліднення ікри, порівняно з ікрою, одержаною від самців, що не отримували вітамінного комплексу.

2. Повторне використання плідників, яким у 2015 році протягом двох місяців до та після нересту і у 2016 році до нересту разом з екструдованими комбікормами давали вітамінну добавку, підвищує збереження життєздатності ікри від першого дня іiі інкубації і до виходу личинки вагою 3 г на $51,1 \%$.

3. Продуктивний ефект личинки райдужної форелі за згодовування плідникам ганаміновіту сприяє зростанню маси личинок при переході на активне живлення.

Перспективи подальших досліджень. Доцільно продовжити дослідження темпу росту різних вікових груп райдужної форелі за дії вітамінної добавки ганаміновіт.

\section{Бібліографічні посилання}

Chrustslev, E.I., Domarkas, A., Goncarenok, O. (2010). Rybovodstvo $\mathrm{V}$ zamknutyh sistemah [Tekst]: monografija. Vilnius (in Russian).

Hrustalev, E.I., Goncharenok, O.E., Kurapova, T.M., Elfimova, K.A. (2014). Ocenka jeffektivnosti kormlenija raduzhnoj foreli na jetapah formirovanija remontno-matochnogo stada $\mathrm{v}$ ustanovkah zamknutogo cikla vodoobespechenija. Tehnologii pishhevoj i pererabatyvajushhej promyshlennosti APK - produkty zdorovogo pitanija. 1, 43-48 (in Russian).

Grudniewska, J., Terech-Majewska, E., Siwicki, A.K. (2011). Profilaktyka W akwakulturze - Dobra Praktyka Higieniczna. W: Nowe gatunki w akwakulturze - rozryd, podchyw, profilaktyka. (Red.)
Zakes Z., Demska-Zakees K., Kowalska A. IRS, Olsztyn. 311-318.

Sharrer, M.J., Summerfelt, S.T., Bullock, G.L. (2005). Inactivation of bacteria using ultraviolet irradiation in a recirculating salmonid culture system. Aquacult. Eng. 33, 135-149.

Smolynets', I.B., Gutyj, B.V., Khariv, I.I., Petryshak, O.Y., Lytvyn R.I. (2016). Pharmaceutical marketing: objectives and types. Scientific Messenger LNUVMBT named after S.Z. Gzhytskyj, 18, 2(69), 151-154. doi:10.15421/nvlvet6929

Hrynevych, N.Ie. (2016). Osoblyvosti vykorystannia biofiltriv $\mathrm{z}$ riznymy typamy napovniuvacha $\mathrm{V}$ ustanovkakh zamknutoho vodopostachannia $\mathrm{v}$ akvakulturi. Nauk. visn. LNUVMBT, Lviv. 18, 3(70), 57-61 (in Ukrainian).

Barylo, Ye.O., Hrynevych, N.Ie. (2015). Morfometrychni ta biokhimichni pokaznyky lychynok lososevykh ryb. Nauk. visn. LNUVMBT, Lviv. 17, 1(61), 11-17 (in Ukrainian).

Vodianitskyi, O.M., Primachov, M.T., Hrynevych, N.Ie. (2016). Vplyv temperaturnoho ta kysnevoho rezhymiv vodnoho seredovyshcha na vyzhyvanist ta rozvytok koropovykh ryb. Naukov.visnyk Natsionalnoho universytetu bioresursiv ta pryrodokorystuvannia. Seriia «Biolohiia, biotekhnolohiia, ekolohiia». 234, 70-78 (in Ukrainian).

Davydov, O.N., Abramov, A.V., Kurovskaja, L.Ja. (2009). Biologicheskie preparaty i himicheskie veshhestva v akvakul'ture. - K.: Logos (in Russian).

Ponomareva, E.N., Syrbulov, D.N., Hramova, A.V. (2005). Ispol'zovanie vitaminov dlja povyshenija effektivno, sti iskusstvennogo vosproizvodstva osetrovyh ryb. Akvakul'tura i integrirovannye tehnologii: problemy i vozmozhnosti: konf.: mater. M.: VNIIR. 2, 291-295 (in Russian).

Shemchuk, V.R., Pirus, R.I. (2002). Preparat dlya pidvischennya imunitetu, yih likuvannya ta profilaktika infektsiynih hvorob. Agrarna nauka - virobnitstvu. 1, 23 (in Ukrainian).

Pukalo, P.Ia. Bozhyk, L.Ia., Bozhyk, O.V. (2015). Dezynfektsiia, yak metod profilaktyky khvorob ryb. Nauk. visn. LNUVM BT, Lviv. 18, 1(65), 134-138 (in Ukrainian).

Стаття надійшла до редакиії 14.02.2017 